\title{
STRATEGI DIGITAL BRANDING LEMBAGA ILMU PENGETAHUAN INDONESIA (LIPI) MELALUI MEDIA SOSIAL
}

\author{
Lyra Vellaniza Ferbita ${ }^{1}$, Yanti Setianti ${ }^{2}$, dan Sussane Dida ${ }^{3}$ \\ Lembaga Ilmu Pengetahuan Indonesia (LIPI) ${ }^{1}$ \\ Universitas Padjadjaran ${ }^{2}$
}

\begin{abstract}
ABSTRAK
Media Sosial menjadi salah satu media yang digunakan LIPI untuk menghilangkan anggapan yang kaku dan birokratis. Media sosial digunakan untuk memasyarakatkan hasil penelitian dan menjadi media untuk melakukan branding yakni melalui strategi digital branding. Tujuan dari penulisan ini adalah mengetahui bagaimana strategi digital branding media sosial LIPI dibuat untuk memasyarakatkan hasil riset dan membentuk citra positif lembaga. Metode penelitian yang digunakan adalah kualitatif dengan studi literatur dan melakukan wawancara dengan pengelola media sosial LIPI dan koordinator media massa LIPI. Adapun hasil penelitian yakni, Tim Humas LIPI dalam membuat strategi digital branding sesuai dengan pendekatan I-Branding yakni, Understanding Customer yakni media sosial dibuat dengan memperhatikan kebutuhan informasi followers yang berbeda-beda pada setiap platform media sosial, Marketing Communication yakni sebagai sebuah brand LIPI memahami pentingnya komunikasi dua arah dengan followersnya agar tercipta komunikasi positif, Interactivity yakni media sosial sebagai wadah berdiskusi dan menstimulasi publik untuk berdiskusi memberikan masukan terkait lembaga, dan Content yakni konten informasi dibuat menarik, mudah dipahami, menggunakan bahasa popular dan telah terverifikasi ilmiah sehingga dapat dipertanggung jawabkan. Dalam mengelola media sosialnya, Tim Humas LIPI melakukan pemetaan khalayak yang menentukan jenis konten dan informasi yang akan diposting di media sosial. Dapat ditarik kesimpulan bahwa dengan keterbatasan dan hambatan dalam peralatan, Sumber Daya Manusia (SDM) dan pendanaan dapat diatasi dengan strategi digital branding yang tepat sehingga salah satu media sosial LIPI yakni Instagram memiliki followers terbanyak se LPNK di bawah Kementerian Riset dan Teknologi RI dan menjadi rujukan informasi sains.
\end{abstract}

Kata-kata Kunci:Digital branding; Media Sosial; Komunikasi; Konten; Strategi Komunikasi

\begin{abstract}
Social Media is one of the media used by LIPI to eliminate the rigid and bureaucratic assumptions. Social media is used to popularize research results and become a medium for branding through a digital branding strategy. The purpose of this paper is to discuss how LIPI's social digital branding media strategy was made to popularize research results and create a positive image of the institution. The research method used was qualitative literature study and interviews with LIPI social media managers and LIPI mass media coordinators. The results are, the LIPI Public Relations Team in creating a digital branding strategy that is in accordance with I-Branding approach, Understanding Customers, namely social media created by taking into account the different information needs of followers on each social media platform, Marketing Communication, LIPI maintain two-way communication with followers in order to create positive communication. Interactivity, social media as a forum for discussion and stimulating the community to give feedback for institutions, and useful content that is made interesting, easy to read, uses popular language and scientific proven. In managing its social media, the LIPI Public Relations Team conducts an audience mapping that determines the type of content and information that will be posted on social media. It can be concluded that with limitations and obstacles in equipment, Human Resources (HR) and funding can be overcome with the precise digital branding strategy so that one of LIPI's social media Instagram has the most followers in the Indonesian State Nonministry Institution under the Republic of Indonesia's Ministry of Research and Technology and becomes a reference science information.
\end{abstract}

Keywords: digital branding;social media;communication;content;communication strategy 


\section{PENDAHULUAN}

Era digital dimulai dengan semakin pesatnya jaringan internet. Kondisi tersebut menyebabkan pergeseran budaya manusia dalam berkomunikasi dan berinteraksi satu sama lain. Era digital juga menyebabkan media massa menyesuaikan diri menjadi media digital yang dapat diakses di jejaring media sosial. Kemampuan media pada masa digital ini sangat memudahkan masyarakat mendapatkan informasi dan membandingkan berbagai sumber berita informasi (Setiawan,2017:2).

Semakin pesatnya pertumbuhan internet membuat adanya perbedaan dalam proses komunikasi dan cara masyarakat mendapatkan informasi. Menurut Gurau (2008:169) terdapat tiga point yang membedakan antara proses komunikasi melalui internet dengan komunikasi klasik yakni: Pertama, adanya interactivity yakni internet dapat membuka peluang komunikasi interaktif dan bersifat dua arah. Kedua, penggunaan internet juga bersifat transparansi yakni semua informasi yang dimuat di media sosial dapat diakses oleh publik manapun. Ketiga, internet mampu menyimpan informasi yang dipublikasikan di web dalam jangka waktu tertentu. Menurut Gurau
(2008:169-184) semakin pesatnya penggunaan internet memunculkan kecenderungan pada publik untuk berkomunikasi secara langsung dengan lembaga dan dapat memilih jenis informasi yang dibutuhkan.

Penggunaan media sosial dalam memasyarakatkan hasil penelitian lembaga riset sudah mulai marak digunakan. Media sosial juga dapat digunakan sebagai cara untuk melakukan digital branding sebuah lembaga. Pemahaman branding seperti yang dijelaskan Kotler (2009:332) branding adalah penamaan, simbol, istilah atau perpaduan dari berbagai konsep yang merepresentasikan sebuah produk, jasa dan perusahaan agar memiliki perbedaan dengan sejenis. Menurutnya, kegiatan branding sangat terkait dengan berbagai kegiatan dan konsep komunikasi yang dilakukan organisasi sebagai upaya branding. Untuk organisasi atau lembaga, pemahaman branding menurutnya bermuara pada persepsi masyarakat bahwa organisasi atau lembaga adalah terbaik dibandingkan organisasi atau lembaga sejenis.

Dalam perkembangannya, dengan semakin luasnya penggunaan internet munculah istilah digital branding, 
penggunaan digital branding menurut

(Dodwani\&Agarwal,2017:31) yakni mulai digunakan pada era berkembangnya internet sebagai media komunikasi. Penggunaan internet adalah metode paling murah dalam membangun branding dibandingkan media tradisional lainnya. Menurutnya, media sosial memainkan peranan penting dalam branding produk. Era digital saat ini, telah mampu secara selektif mendorong pengguna media sosial untuk berkunjung ke laman media sosial seperti instagram berdasarkan minat dan riwayat penjelajahan atau browsing pengguna tersebut sebelumnya.

Pemahaman terkait digital branding juga dijelaskan Lotta Back (2018:2), digital branding yakni saluran digital dan asett sebagai positioning jasa atau produk yang digunakan untuk mengkomunikasikan merek dan sebagai bagian dari program komunikasi. Oleh karena itu, digital branding dapat menjadi strategi bisnis dan perencanaan merek yang membuat image dan citra lembaga menjadi berbeda.

Menurut Smart Insight 2015 dalam Lotta Back (2018:4) digital branding dapat diartikan sebagai digital communication yang memiliki konteks yang kuat terkait strategi bisnis dan perencanaaan merek. Sehingga, meskipun melakukan branding, digital branding atau digital communication, elemen kuncinya adalah bagaimana membuat brand berbeda dari yang lain.

Selain itu, dalam media digital seperti media sosial, khalayak merupakan para pencari informasi dengan intensitas tinggi dan media sosial menjadi satu-satunya platform digital yang menjalankan komunikasi dua arah antara perusahaan brand dan khalayak. Digital media dianggap sebagai platform media terbaik untuk melekatkan brand pada khalayak, karena dapat menjangkau khalayak secara efektif. Menurut Dodwani\&Agarwal (2017:36) platform media digital dapat melibatkan khalayak untuk benar-benar merasakan bagaimana asosiasi brand dan dapat diandalkan dalam proses branding.

Max Weber menjelaskan kehadiran media sosial memiliki peran dalam proses branding. Sebagai contoh dalam konsep marketing konvensional atau tradisional dimana penjual harus melakukan proses komunikasi yang panjang dengan calon konsumen untuk meyakinkan kualitas produk. Sedangkan, branding sangat 
menekankan tentang bagaimana keterlibatan konsumen dalam media sosial yang memungkinkan adanya ruang interaksi yang dinamis untuk berdiskusi tentang brand (Putri\&Mardalis,2017:52). Kolom komentar pada media sosial memberikan ruang pada followers untuk berdiskusi dan menceritakan pendapatnya tentang konten sains yang diposting.

Pada era globalisasi saat ini memang diperlukan kemampuan manajemen dalam mengelola dan membangun citra lembaga menjadi brand (Kotler\&Amsstrong,2010). Hal ini dikarenakan brand adalah sebuah aset yang luar biasa mampu merepresentasikan inti lembaga dan perusahaan oleh karena itu manajemen harus berhati-hati dalam membangun dan mengelola brand.

Branding dalam era digitalisasi memiliki pendekatan tersendiri sehingga diperlukan strategi dan taktik dalam mengelolanya. Hal ini terutama dengan semakin berkembangnya media sosial sehingga proses branding menjadi terintegrasi dan saling terkait.

Konsep digitalisasi saat ini telah menjadi bagian dalam hidup manusia yang menunjukan adanya interaksi antara perusahaan dengan publiknya. Menurut Kaplan\& Haenlein (2010) digitalisasi dengan media sosial telah dianggap sebagai transformasi dari metode untuk melihat perilaku publiknya secara signifikan. Apalagi di era saat ini, publik biasanya menghabiskan banyak waktu untuk mengakses internet. Adanya internet mobile dan sosial media telah membuat sebuah teknologi baru berbasis saluran untuk berkomunikasi dengan publiknya yang biasa disebut sebagai saluran digital dan transformasi digital (Lotta Back,2018:10).

Pengertian brand menurut Kotler (2008:258) dalam Asosiasi Marketing Amerika dijelaskan bahwa brand adalah lambang, simbol, atau desain maupun perpaduan dari ketiganya untuk menginterpretasikan sebuah layanan atau produk dari sebuah perusahaan. Brand dapat menjadi pembeda dan ditujukan untuk memberikan layanan memuaskan untuk pengguna. Pembeda yang dimaksud biasanya bersifat emosional dan mampu mendorong pengguna untuk menjalin hubungan dengan brand tersebut.

Penggunaan bahasa yang biasa digunakan dalam media sosial khususnya instagram adalah bahasa 
popular atau bahasa sehari-hari yang mudah dipahami oleh pengguna. Hal ini tentunya sangat penting agar komunikasi dan penyampaian pesan dapat berjalan efektif. Keunggulan platform media sosial adalah kemampuan untuk memviralkan sebuah postingan dari Brand. Organisasi yang menjalankan digital branding biasanya menginginkan brand nya menjadi topik pembicaraan secara massive di media sosial

(Tsimonis\&Dimitriadis, 2014:334). Salah satu contohnya tentang proses viral brand dapat terjadi yakni melalui aplikasi Facebook, tombol Suka atau Bagikan, opsi Tweet ulang adalah beberapa cara untuk membuat pesan atau nama merek dikenal sangat cepat pada Twitter, opsi share dan like pada Instagram.

Pada era digital branding, lembaga atau perusahaan bukan yang menentukan merk tetapi justru khalayak dalam media sosial platform yang menjadi penentu bagaimana sebuah brand Dodwani\&Agarwal (2017:36). Dalam membangun brand dalam media sosial, khalayak media sosial cenderung memiliki ketertarikan yang sama pada sebuah brand. Hal ini dapat diketahui bagaimana khalayak memfollow media sosial dan terlibat dalam diskusi tentang brand.

Pada umumnya lembaga pemerintah atau Lembaga Pemerintah Non Kementerian (LPNK) cenderung terstruktur dan kaku, untuk itulah diperlukan saluran media digital yang memiliki konsep millenials untuk membangun image positif yang lebih baik dari lembaga. Dodwani\&Agarwal (2017:32) menjelaskan tujuan utama dari digital branding yakni membangun kesadaran publik tentang brand dan layanan sekaligus membangun reputasi yang lebih baik yang tentunya mendorong lembaga untuk berpikir inovatif dalam membuat konten dan merepresentasikan ide.

Lembaga Ilmu Pengetahuan Indonesia (LIPI) sebagai Lembaga Pemerintah Non Kementerian (LPNK) yang bergerak pada bidang riset, memiliki tanggung jawab untuk memasyarakatkan hasil penelitian kepada masyarakat luas. Adapun yang termasuk LPNK dibawah Kementerian Riset dan Teknologi (Kemenristek) diantaranya Lembaga Ilmu Pengetahuan Indonesia (LIPI), Badan Standardisasi Nasional (BSN), Lembaga Penerbangan dan Antariksa Nasional (Lapan), Badang Pengkajian dan Penerapan 
Teknologi (BPPT), Badan Informasi dan Geospasial (BIG), Badan Tenaga Nuklir Nasional (Batan), dan Badan Pengawas Nuklir (Bapeten). Ketujuh badan dan lembaga tersebut berada dibawah koordinasi Kemenristek dan melakukan kajian serta hasil riset sesuai dengan tugas dan fungsi masingmasing.

Lembaga Ilmu Pengetahuan Indonesia (LIPI) memiliki 5 (lima) jenis riset sesuai dengan ranah bidang keilmuannya meliputi Bidang Ilmu Pengetahuan Hayati (IPH), Bidang Ilmu Pengetahuan Sosial dan Kemanusiaan (IPSK), Bidang Ilmu Pengetahuan Teknik (IPT), Bidang Ilmu Pengetahuan Kebumian (IPK), dan Bidang Jasa Ilmiah (Jasil). Kelima bidang penelitian tersebut menjalankan fungsinya dengan melakukan penelitian pada bidang keahliannya tersebut. Output hasil penelitian biasanya berupa buku dan jurnal yang dipublikasikan dan dikumpulkan dalam perpustakaan sebagai referensi penelitian selanjutnya. Padahal hasil penelitian tersebut bermanfaat dan harus diketahui oleh masyarakat luas. Hal ini karena anggaran riset LIPI berasal dari pemerintah sehingga hasil dan temuan riset harus diketahui oleh pemerintah, stakeholders, dan masyarakat.

Adanya image atau budaya yang sudah terbentuk bahwa LPNK adalah lembaga yang ketinggalan jaman dan cenderung birokratis dalam menyampaikan informasi, menjadi salah satu hambatan dalam menjalankan komunikasi efektif dengan publiknya yakni masyarakat luas dan stakeholder. Penyampaian hasil riset tidak hanya melalui jurnal dan buku karena tidak semua masyarakat mampu memahami bahasa dan ulasan sains tersebut. Hal ini karena tingkat pendidikan dan pengetahuan yang berbeda-beda dimiliki oleh publik LIPI. Untuk itu, diperlukan terobosan dalam menyampaikan informasi sains agar menjadi ringan dan mudah dipahami.

Menyikapi hal tersebut, LIPI berupaya melakukan penguatan digital branding agar menguatkan kembali citra lembaga lebih positif dan mendorong millenial dan masyarakat untuk tertarik pada riset. Upaya tersebut dilakukan dengan menggunakan media sosial yang mampu menampilkan foto dan caption yang menarik yang merepresentasikan lembaga dengan image yang lebih positif. Menurut Tsimonis\&Dimitriadis 
media sosial sangat membantu dalam popularitas organisasi dikalangan publiknya. Penggunaan media sosial dapat dijadikan strategi dalam proses branding lembaga dengan konten menarik dan bermanfaat untuk masyarakat luas sebagai upaya mendorong ketertarikan dan menjadikan media sosial LIPI sebagai rujukan nasional informasi terkait sains dan iptek.

Media sosial dapat menjalin keterikatan dengan publiknya dan memberikan akses pada organisasi untuk berkomunikasi secara nonstop dengan biaya yang murah. Followers dapat saling berdiskusi dengan hitungan menit (Tsimonis \&Dimitriadis, 2014:335). Cara berkomunikasi ini dapat menimbulkan rasa keterlibatan dan engagement antara pengguna media sosial dan brand sehingga manfaat yang diharapkan adalah tercapainya citra positif dan menjadi media sosial sebagai rujukan informasi sains di Indonesia. Oleh karena itu, tulisan ini bertujuan menjabarkan strategi digital branding LIPI yang dilakukan melalui media sosial untuk memasyarakatkan informasi hasil riset dan menjadi rujukan informasi sains sehingga terbentuk citra positif masyarakat pada lembaga.

\section{METODE PENELITIAN}

Metode yang digunakan yakni dengan pendekatan kualitatif dengan jenis penelitian studi kasus deskriptif. Penelitian deskriptif adalah upaya melakukan penelitian dengan melihat fakta dan intepretasi yang tepat (Natasha,dkk, 2019:80). Metode penelitian kualitatif yakni proses penelitian yang menyajikan data deskriptif yang dapat diarahkan dan peneliti melakukan pengamatan pada individu dan kondisi secara utuh (Pratama,2012:12).

Data yang diperoleh penulis yakni melalui studi literatur dari buku dan jurnal yang relevan. Data juga diperoleh melalui situs terpercaya yang menyampaikan data-data akurat tentang suatu fenomena dan menyajikan data yang valid. Penulis juga mengambil data berdasarkan postingan di media sosial milik LPNK dilingkungan Kemenristek untuk kemudian diolah. Adapun media sosial yang dimaksud adalah Instagram, Facebook, Twitter, dan You Tube. Sebagian besar data dapat diperoleh melalui dokumentasi dan laporan. Keutamaan data adalah tidak hanya sebatas kurun waktu 
tertentu sehingga dapat digali oleh peneliti untuk mendapatkan informasi yang dibutuhkan. Bahan melalui dokumentasi meliputi kumpulan pemberitaan, dokumen pemerintah, informasi yang tersimpan dalam jaringan, memori internet dan website (Herdiansyah, 2010:143).

Lebih lanjut, data juga diperoleh melalui studi pustaka melalui buku, jurnal, literatur, laporan terkait yang memiliki keterkaitan dengan permasalahan penelitian (Nazir,2013:111).

Untuk mendapatkan informasi lebih komprehensif, peneliti juga melakukan wawancara dengan Tim Humas LIPI yang mengelola media sosial LIPI dan koordinator media massa LIPI. Proses wawancara dilakukan untuk menggali lebih dalam tentang proses perencanaan strategi dan taktik yang digunakan oleh Tim Humas LIPI dalam upaya digital branding. Wawancara dilakukan juga sebagai upaya menemukan hambatan dan peluang positif yang dihadapi Tim Humas LIPI dalam proses digital branding. Menurut Mulyana (2010:180) teknik pengumpulan data dengan wawancara adalah proses komunikasi bersifat dua arah dimana terdapat pihak yang menggali informasi dengan memberikan pertanyaan dengan dasar sebuah tujuan. Peneliti dapat mengerti tentang permasalahan secara komprehensif tentang permasalahan tertentu terutama saat memahami fenomena dan situasi yang dihadapi.

\section{HASIL DAN PEMBAHASAN}

Persebaran jaringan internet yang semakin merata di Indonesia memunculkan data proyeksi pengguna internet hingga 2023. Berdasarkan sumber dari Statisia yang dikeluarkan oleh Databoks/Kataddata.co.id yakni situs data online menunjukan data sebagai berikut,

\section{Tabel 1. Proyeksi Pengguna Internet}

\section{0-2023}

\begin{tabular}{cc}
\hline Tahun & Jumlah \\
& Pengguna \\
& Internet \\
& (dalam \\
& Juta) \\
& 119,4 \\
\hline 2020 & 131 \\
2021 & 141,3 \\
2022 & 149,9 \\
2023 & \\
\hline
\end{tabular}

Sumber: Statista Kata Data.co.id

Jumlah pengguna internet diprediksi semakin meningkat bahkan hingga 2023 mencapai 149,9 juta pengakses internet di Indonesia. Hal ini 
menunjukan bahwa proses komunikasi branding dapat optimal dilakukan karena semakin luas jangkauan penggunaan internet. Bahkan branding pada media sosial telah digunakan sebagai bagian dari strategi pemasaran perusahaan agar mampu menjaring perhatian publik.

LIPI menyadari bahwa proses branding tidak mudah dilakukan oleh lembaga riset tertua di Indonesia. Hal ini dikarenakan citra dan branding yang identik dari lembaga pemerintah adalah ketinggalan jaman dan tidak up date. Oleh karena itu, Tim Humas LIPI memutuskan untuk melakukan digital branding sebagai upaya untuk menghidupkan kembali image dan citra LIPI yang tidak terkesan birokratis dan kaku tetapi mulai popular dalam memasyarakatkan hasil riset. Dalam dunia digital, persebaran informasi dapat dilakukan melalui media sosial dan platform lainnya. Komunitas online dan jaringan sosial telah membantu individu untuk menyampaikan opini, pengalaman, pemikiran dan perasaan tentang berbagai topik dan terkait brand (Lotta Back,2018:5).

Menurut Tsimonis \& Dimitriadis, (2014:329) tantangan organisasi yang dihadapi saat menggunakan media sosial sebagai branding adalah saat berkomunikasi dan merespon komentar negatif karena apabila tidak efektif dalam mengatasi situasi tersebut maka dapat berdampak negatif pada word of mouth diantara pengguna sosial media. Apabila organisasi gagal dalam membuat strategi yang tepat untuk merespon hal negatif tersebut maka akan berdampak negatif pada branding organisasi (Lotta Back, 2018:9). Untuk itu diperlukan strategi perencanaan managemen brand yang tepat. Berikut adalah Brand Management Model SOSTAC menurut Chaffey \& Smith (2013:3) dan SmartInsight 2016. Menurutnya, model ini adalah sistem perencanaan untuk pengembangan dan mengelola strategi digital branding yang dikombinasikan dengan teknik komunikasi digital.

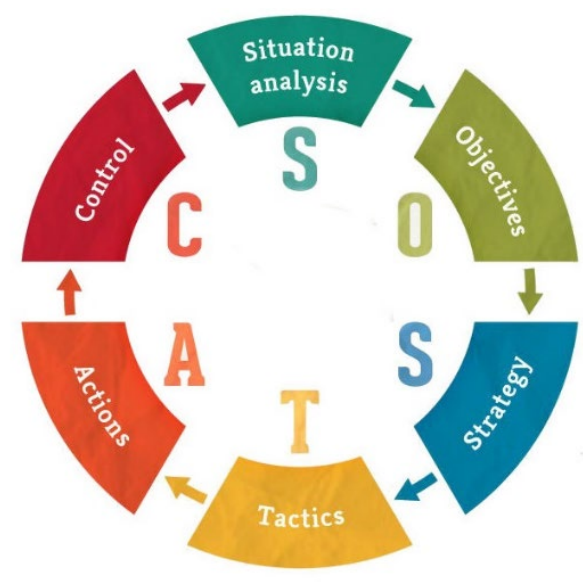

Sumber: Chaffey\&Smith (2013:3)

Gambar 1, Brand Management Model 
SOSTAC adalah singkatan dari Situation, Objectives, Strategy, Tactics, Action and Control (Chaffey\&Smith, 2013:3). Lebih lanjut, dalam digital branding melalui media sosial, Tim Humas LIPI tentu melakukan perencanaan dalam pengelolaan brand dengan pemahaman sebagai berikut Pertama, Situation Analysis adalah analisis situasi dari organisasi tim Humas LIPI menyadari bahwa sebagai lembaga riset tertua milik pemerintah LIPI harus memasyarakatkan hasil penelitian sebagai bagian dari tugas dan fungsi sekaligus tetap bersifat netral. Kedua. Objectives adalah tujuan dari perencanaan brand, branding adalah menjadikan media sosial LIPI sebagai rujukan informasi sains dan iptek. Hal ini agar citra dan image LIPI dapat lebih positif dan masyarakat tertarik pada iptek dan inovasi. Ketiga, Strategy adalah membuat perencanaan untuk mencapai tujuan, Tim Humas LIPI berupaya membuat strategi yang fokus pada digital branding. Keempat, Tactics adalah detail kegiatan untuk mengimplementasikan strategi diantaranya dengan menggunakan media sosial sebagai media digital branding. Kelima, Action adalah rencana aksi untuk mengimplementasikan strategi yang meliputi tanggung jawab dan deadline kegiatan, dalam membuat perencanaan Tim Humas LIPI juga membuat time table agar perencanaan berjalan lancar. Keenam, Control yakni bagaimana mengelola proses strategi yakni mengukur, memonitor dan memodifikasi apakah sesuai target. Dalam melaksanakan strategi dan taktiknya Tim Humas LIPI juga melakukan kontrol dengan meminta laporan mingguan dari pengelola media sosial terkait kegiatan dan target yang sudah dicapai.

Pada aspek objectives menurut Lotta Back (2018:15) terdapat 5 (lima) konsep dalam menyusun tujuan organisasi yakni SMART (Specific, Measurable, Actionable, Relevant, Time-related). Konsep SMART ini dapat digunakan untuk mengukur tujuan dari perencanaan digital branding oleh organisasi. Specific adalah apakah organisasi telah mengidentifikasi spesifik isu dan tantangan yang dihadapi, Measureable adalah bagaimana perencanaan untuk menilai performance dan memonitor program yang berjalan, Actionable adalah bagaimana menentukan tujuan yang dapat meningkatkan kinerja organisasi, 
Relevant adalah menentukan isu yang relevan dan dapat dicapai oleh tim digital branding, Time-related adalah menentukan deadline waktu yang tepat pada setiap pelaksanaan program.

Seperti yang dijelaskan dalam SOSTAC bahwa merancang digital branding tentunya diperlukan strategi komunikasi yang tepat. Seperti yang jelaskan Cangara (2014:64) strategi adalah perencanaan untuk melakukan perubahan pada perilaku manusia melalui ide yang baru. Untuk itu diperlukan perencanaan yang matang dan memperhatikan ruang lingkupnya. Selain itu, R. Wayne Pace, Brent D. Peterson, dan M.Dallas Burnett dalam Zainal (2015:115) menjelaskan terdapat 3 (tiga) tujuan utama dari strategi komunikasi yakni: (1). To secure understanding yakni menjaga bahwa proses komunikasi berjalan efektif dan publik memahami konten yang disampaikan, (2). to establish acceptance yakni membangun kepercayaan dengan publik, (3). To motivate action yakni bertujuan mendorong publik untuk bertindak sesuai dengan pesan yang disampaikan.

Strategi utama yang dipergunakan LIPI dalam proses digital branding di media sosial yakni dengan memahami tujuan dan target yang akan dicapai sesuai dengan platform media sosialnya. Penggunaan media sosial dalam branding ditentukan oleh tujuan dari penggunaanya (Zarrella,2009:3). LIPI menyadari bahwa usia dari target khalayak untuk menerima informasi terkait iptek adalah dari berbagai usia sehingga diputuskan menggunakan 4 (empat) platform media sosial yakni Facebook, Instagram, Twitter, dan You Tube.

Media sosial yang semakin berkembang adalah bagian dari kecanggihan dan peningkatan kemampuan aplikasi berbasis media baru. Penggunaan media sosial tentunya memudahkan masyarakat secara luas untuk berinteraksi dan berdiskusi meskipun tidak bertatap muka bahkan membentuk komunitas berdasarkan kesamaan minat.(Putri\&Mardalis,2017:52).

Menurut Tim Humas LIPI, melalui konten yang diposting di media sosial resmi milik LIPI biasanya followers akan berbagi cerita dan pendapat tentang konten sains dan memungkinkan terbentuknya diskusi dari penyuka sains. Hal inilah yang menjadi salah satu wadah untuk proses pembentukan brand oleh followers. 
Berikut adalah jumlah followers media sosial LIPI pada 2020.

Tabel 2. Jumlah Followers di Media Sosial LIPI per April 2020

\begin{tabular}{cc}
\hline $\begin{array}{c}\text { Media } \\
\text { Sosial }\end{array}$ & $\begin{array}{c}\text { Jumlah } \\
\text { Followers }\end{array}$ \\
\hline Instagram & 142,000 \\
Facebook & 109,616 \\
You & 63,400 \\
Tube & \\
Twitter & 10,700 \\
\hline
\end{tabular}

Sumber: lipi.go.id

Berdasarkan data tersebut, media sosial Instagram memang menempati urutan pertama dengan jumlah followers terbanyak yakni 142,000, Facebook 109,616 followers, You Tube 63,400 followers, dan Twitter 10,700 followers. Sebagai pemilik followers terbanyak, instagram menjadi fokus dalam proses branding, meskipun demikian Facebook, You Tube dan Twitter juga memiliki jumlah followers yang cukup potensial untuk proses digital branding. Pemahaman followers yakni menurut Soraya (2017:33) dalam bersosialisasi di media sosial khususnya instagram diperlukan untuk menjadi pengikut atau followers sehingga proses komunikasi dan informasi dapat bersifat dua arah.
Followers adalah bagian penting dalam media sosial karena dapat menunjukan kepopuleran sebuah akun media sosial. Banyaknya jumlah followers media sosial Instagram membuat proses promosi iptek menjadi lebih efektif dan menjadi prioritas dalam pengembangan konten sains. Media sosial menjadi cara untuk menarik audiens baru dan manfaat yang bahkan lebih penting bagi merek adalah kemungkinan untuk menargetkan aksinya pada kelompok penggemar tertentu. Sehingga mereka dapat menerapkan strategi media sosial mereka sesuai dengan profil followersnya minim (Tsimonis\&Dimitriadis, 2014:335).

Tim Humas LIPI juga membuat konten yang berbeda dalam setiap media sosial. Dalam pengklasifikasian tersebut, Instagram menjadi fokus utama karena memiliki followers terbanyak, beragam dan pengelolaan konten yang lebih mudah dan banyak menarik atensi followers. Sedangkan Facebook dengan followers mayoritas adalah baby boomers dan konten yang biasa di share dalam media sosial ini adalah video panjang dan berita-berita dari laman website LIPI. Sedangkan untuk twitter, cenderung bersifat stagnan dan bisa menggunakan bahasa 
santai untuk membahas sains namun, postingan konten tidak maksimal seperti Instagram. Untuk Youtube, konten yang dipublish biasanya seperti film pendek yang menampilkan perjalanan riset LIPI dan ekspedisi yang dilakukan oleh LIPI. Setiap konten yang akan dimuat oleh Tim Humas LIPI tentunya memperhatikan berbagai aspek diantaranya kategori usia followersnya dan jenis konten yang diminati. Hal ini dapat terlihat dari feedback yang diberikan kepada Tim Humas LIPI yang dikirimkan followers melalui direct message dan kolom komentar. Selain itu, dalam mengidentifikasi jenis konten yang diminati juga dapat dilihat dari banyaknya jumlah like dalam setiap postingan yang di unggah. Sebagai contoh, untuk facebook yang mayoritas pengikutnya adalah baby boomers maka konten promosi dan branding dibuat dengan bahasa yang formal dan dengan sedikit bahasa popular. Video panjang yang dimuat di facebook biasanya akan di share oleh followers dan ditonton oleh followers yang besaran jumlahnya dapat dilihat pada setiap postingan.

Proses branding di media sosial juga memerlukan konten visual yang kuat dan atraktif yang merepresentasikan tugas dan fungsi
LIPI sebagai lembaga riset tertua milik pemerintah. Tim Humas khususnya media sosial LIPI memahami bahwa konteks tertua menimbulkan kesan jadul dan ketinggalan jaman atau usang, sehingga diperlukan pembaharuan dan penyegaran melalui media sosial dengan penggunaan bahasa popular dan mudah dipahami. Menurut Effendy (2003:45) bahwa faktor yang menyebabkan kegagalan dalam komunikasi adalah adanya perbedaan bahasa yang digunakan komunikator (media sosial) dengan yang digunakan khalayak. Selain itu, struktur bahasa yang digunakan cenderung kaku dan tidak lazim juga menjadi kendala proses komunikasi efektif. Hal inilah yang dihindari oleh Tim Humas LIPI setiap membuat konten media sosial.

Proses branding juga terkait dengan tujuan yang ingin dicapai seperti image dan citra positif sebagai lembaga riset yang menjadi rujukan informasi sains. Oleh karena itu, terkait konten Tim Humas LIPI sangat mengutamakan konten tentang aktivitas dan hasil riset LIPI daripada pemberitaan bersifat seremonial. Hal ini dilakukan karena Tim Humas LIPI menyadari followers lebih tertarik pada informasi tentang riset dan aktifitas LIPI. Selain itu, 
informasi terkait riset dan inovasi iptek dapat lebih bermanfaat untuk masyarakat luas. Jenis konten tersebut selalu dibahas dalam perencanaan yang dilakukan oleh Tim Humas LIPI pada setiap bulannya. Tim Humas LIPI memahami pentingnya peranan perencanaan dan manajemen dalam keberhasilan konten. Menurut Lengkong, Sondakh, dan Londa (2017:9) menyusun sebuah perencanaan strategi tidak hanya sebagai penunjuk arah kegiatan saja tetapi justru sebagai peta kegiatan operasionalnya. Tim Humas LIPI menyadari pentingnya dalam perencanaan strategi konten media sosial sehingga melakukan rapat redaksi yang melibatkan peneliti agar dapat mengidentifikasi riset yang perlu dipublish.

Dalam pengelolaan konten iptek dan sains, Tim Humas LIPI juga bekerjasama dengan pranata humas yang berada di pusat penelitian diseluruh Indonesia. Hal ini dilakukan agar informasi dalam konten media sosial selalu update. Selain itu, Tim Humas LIPI menyadari bahwa dalam membuat konten menarik dan kreatif diperlukan passion sehingga tim konten adalah usia millenials dan memiliki passion dalam konten kreatif media sosial. Hal ini karena mayoritas khalayak pengguna media sosial adalah usia millenials yang juga menjadi salah satu target khalayak dalam proses digital branding. Menurut Zarrella (2009:16) pada saat publik atau target khalayak sebuah perusahaan telah menggunakan media sosial, maka tidak ada alasan bagi perusahaan tersebut untuk tidak menggunakan media sosial sebagai sarana pemasaran branding. Penggunaan media sosial hampir tidak ada biaya kecuali untuk mempersiapkan konten-konten yang kuat dan memerlukan skill. Oleh karena itu, menurut Tim Humas LIPI dengan keterbatasan biaya dan peralatan maka media sosial menjadi salah satu strategi yang tepat dalam proses digital branding. Tekanan untuk pengurangan biaya dalam publikasi, biasanya membuat organisasi berupaya menemukan solusi promosi yang murah tetapi hasil maksimal sehingga mereka menggunakan media sosial untuk memperkenal brand secara optimal dengan biaya yang minim (Tsimonis\&Dimitriadis, 2014:334).

Strategi selanjutnya yakni, melalui penamaan media sosial, Tim media sosial LIPI konsisten dengan 
menggunakan nama LIPI Indonesia sebagai nama platform branding di media sosial. Hal ini tentunya bertujuan agar dalam proses digital branding dapat tercapai brand awareness dan media sosial LIPI menjadi rujukan informasi ilmiah. Pemahaman brand awareness yakni kepekaan dari keberadaan merek dalam pikiran dan perasaan konsumen sehingga menjadi faktor penentu kategori (Darmadi durianto,2004:6). Terkait munculnya ketegori Paul dan Olson (2000:190) menjelaskan bahwa brand awareness sebagai tujuan dari proses komunikasi yang dilakukan dalam strategi komunikasi. Tujuan dari brand awareness adalah menjadikan brand pertimbangan dalam mengambil keputusan saat akan memilih sumber informasi (Rustandi, 2018:12). Oleh karena itu, penamaan menjadi faktor penting dikarenakan unsur kategori melekat pada penamaan tersebut.

Tim Humas LIPI juga menetapkan kriteria tentang konten yang layak untuk dimuat dimedia sosial. Adapun kriteria tersebut yakni, hasil penelitian dan temuan penelitian harus sudah terverifikasi secara ilmiah dan untuk hasil riset diutamakan yang sudah memiliki paten atau sudah dimuat di jurnal terakreditasi. Hal ini penting agar tanggung jawab secara kode etik penelitian terpenuhi. Menurut Ryan (2009:77) bahwa tantangan terbesar dalam digital branding adalah membuat konten yang tepat yang relevan dan menarik hati publik. Hal ini dapat diraih dengan fokus pada minat khalayak daripada kepentingan brand itu sendiri. Bahkan menurut Zarrella (2009:15) digital branding akan sangat optimal apabila lebih fokus pada kebutuhan audiens pada jenis informasi daripada membuat konten promosi yang tidak bermanfaat untuk audiens. Hal inilah yang membuat media sosial LIPI hanya menampilkan aktifitas riset dan informasi iptek yang diperlukan audiens dan tidak menampilkan informasi yang bersifat seremonial.

Selain itu, salah satu strategi yang digunakan oleh Tim Humas adalah dengan menggunakan infografis dalam setiap postingan yang berisi angka, data dan penelitian. Hal ini dilakukan agar data statistik dan proses riset tersebut 
mudah dipahami. Tim Humas LIPI berkomitmen meskipun dengan keterbatasan pada peralatan untuk membuat konten, namun media sosial LIPI khususnya Instagram memiliki followers terbanyak di antara LPNK yang lainnya.

\begin{tabular}{|c|c|}
\hline LPNK/Akun Instagram & \multirow{2}{*}{$\begin{array}{c}\begin{array}{c}\text { Jumlah } \\
\text { Followers }\end{array} \\
142,000\end{array}$} \\
\hline Pengetahuan & \\
\hline Indonesia/@lipiindonesia & \\
\hline Standardisasi & 88,1000 \\
\hline Nasional/@bsn_sni & \\
\hline Lembaga Penerbangan dan Antariksa & 68,200 \\
\hline Nasional/@lapan_ri & \\
\hline $\begin{array}{l}\text { Badan Pengkajian dan Penerapan } \\
\text { Teknologi/@bppt_ri }\end{array}$ & 45,800 \\
\hline Informasi & 30,000 \\
\hline Geospasial/@infogeospasial & \\
\hline Tenaga & 18,600 \\
\hline Nasional/@badan_tenaga_nuklir_nas & \\
\hline Badan Pengawas Nuklir/@bapeten & 14,200 \\
\hline
\end{tabular}

\section{Tabel 3. Jumlah Followers Instagram}

\section{LPNK dibawah Kemenristekdikti}

Sumber: Instagram LPNK

Berdasarkan Tabel 3, Instagram LIPI berada diposisi pertama dengan jumlah followers terbanyak yakni 142,000 followers. LIPI adalah LPNK dibawah koordinasi Kementerian Riset dan Teknologi atau Badan Riset Inovasi Nasional. Tabel 3 menunjukan jumlah folowers yang memiliki perbedaan cukup signifikan hal ini dapat mengindikasikan informasi LIPI cukup diminati dan menjadikan Instagram LIPI sebagai rujukan informasi sains. Menurut Lotta Back (2018:8) social media adalah wadah terjadinya percakapan. Hal ini terkait bagaimana menjangkau target khalayak dan mampu memanfaatkan waktu yang dimiliki audiens untuk berinteraksi dengan pengelola media sosial platform. Organisasi dan lembaga saat ini semakin menyukai penggunaan media sosial sebagai media branding. Selain itu, organisasi atau perusahaan telah mampu menciptakan komunitas pada followers media sosial yang dapat digunakan untuk kegiatan branding (Tsimonis\&Dimitriadis 2014:330). Hal tersebut dipahami oleh pengelola media sosial LIPI, dalam kolom komentar biasanya followers menanyakan dan berkomentar untuk bertanya terkait postingan. Pada situasi tersebut, Tim Humas LIPI menyadari pentingnya untuk merespon dan menjawab pertanyaan tersebut sebagai proses komunikasi dua arah. Pemilihan bahasa yang digunakan juga dalam 
konteks bahasa popular sehingga komunikasi efektif dapat terjadi. Tim Humas LIPI selalu menampung masukan dari followers dan mencoba merealisasikannya. Salah satu contoh dari kegiatan yang banyak mendapat masukan dari followers adalah informasi terkait ekspedisi penelitian untuk dimuat dalam instagram atau LIPI diminta menjawab mitos tentang tumbuhan yang beracun dan tumbuhan obat.

Selain itu, Tim Humas LIPI sering melakukan kuis yang berhadiah merchandise LIPI. Pertanyaan biasanya seputar sains, hal ini dilakukan agar proses komunikasi dan transfer knowledge dapat terjadi antara followers dan peneliti melalui postingan di media sosial. Metode kuis adalah bagian dari konten media sosial agar tidak membosankan sekaligus dapat menyampaikan hasil riset secara menarik melalui pertanyaan yang singkat. Menurut Tsimonis\&Dimitriadis (2014:334), terdapat dua aktivitas penting dalam media sosial yakni dengan membuat kompetisi yang berhadiah seperti pemberian kupon, diskon dan produk hadiah. Selain itu, berkomunikasi hampir setiap hari kepada followers di media sosial agar membuat publik tertarik dengan brand.

Khusus media sosial Instagram, Tim Humas LIPI membuat lebih tersegmentasi dan memiliki tema tertentu pada jenis ilmu pengetahuan. Sebagai contoh Tim menggunakan istilah "SEHATI" atau Senin Belajar Ilmu Kehati, “TuesdayTech" atau Selasa Belajar Ilmu Teknik, "RabuMi" atau Rabu Belajar Ilmu Kebumian, "KamiSosial" Kamis Belajar Ilmu Sosial. Istilah-istilah tersebut digunakan untuk membuat followers tertarik untuk mempelajari sains. Selain itu, dalam postingan instagram juga memberikan ucapan khusus untuk hari-hari nasional atau hari keagamaan. Menurut Tsimonis\&Dimitriadis (2014:334) media sosial sangat ideal untuk menyebarkan informasi tentang organisasi dari mulut ke mulut yang kemudian followers dapat membagikannya. Oleh karena itu, penting membuat konten yang mampu menarik dan disukai khalayak.

Khusus media sosial, LIPI juga melakukan monitoring dan evaluasi. Proses ini juga melihat pemberitaan media massa tentang hasil riset LIPI yang yang diposting di media sosial. Pemberitaan tersebut kemudian 
dianalisis sesuai dengan intonasi pemberitaanya. Kendala yang dihadapi Tim Humas LIPI dalam pengelolaan konten adalah terkait penempatan isu dan netralitas terutama pada konten sensitif terkait pemilu, pilkada dan isu sosial dan politik lainnya. Hal ini dikarenakan, brand LIPI adalah lembaga riset pemerintah yang bersifat netral dan tidak memihak. Oleh karena itu, Tim Humas LIPI melakukan seleksi dalam konten yang akan dimuat di media sosial. Sebuah konten tentu akan mempengaruhi citra dan image lembaga yang bermuara ada branding.

Dalam melakukan strategi digital branding, Tim Humas LIPI sebagai admin media sosial juga melakukan promote $I G$ untuk media sosial Instagram, hal ini dilakukan un meningkatkan awareness penggı tentang sains dan menarik follow baru untuk mengikuti instagram LI Paid promote atau promosi berba adalah dapat berupa konten prom yang dapat mendorong pengguna me sosial tertarik untuk melihat lebih lanjut. Upaya tersebut dilakukan untuk meningkatkan nilai jual dan promosi pada layanan dan brand LIPI hal ini terkait dengan pemahaman brand equity. Menurut Kotler\&Keller
(2016:17) brand equity yakni proses meningkatnya nilai pada jasa atau produk yang bisa berpengaruh pada pemikiran, konasi dan afeksi terhadap sebuah brand. Hal ini karena brand equity memberikan value pada khalayak dan lembaga. Tim humas LIPI berupaya memberikan value added pada brand lembaga yakni LIPI. Penguatan brand ini dilakukan dengan pemilihan platform media sosial.

Selain itu, media sosial LIPI juga memiliki acuan sesuai dengan Peraturan Menteri Pendayagunaan Aparatur Negara dan Reformasi Birokrasi (Kemenpan RB) No. 83/2012 Tentang Pemanfaatan Media Sosial Instansi Pemerintah sesuai Gambar 2.

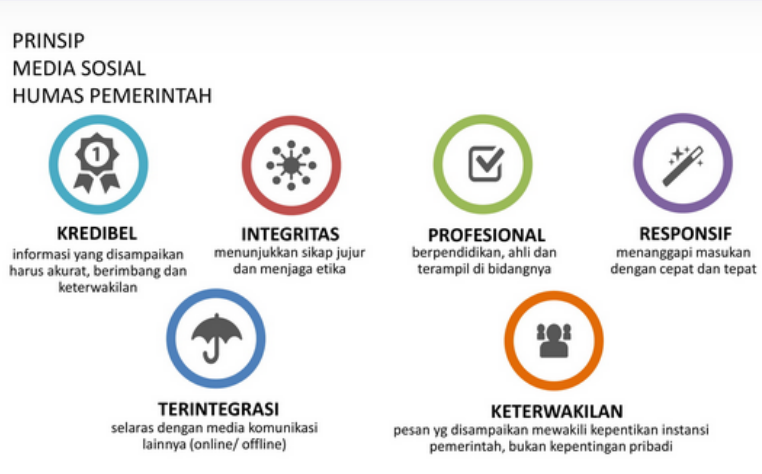

Sumber : Kemenpan.go.id

Gambar 2: Prinsip Media Sosial Humas Pemerintah

Berdasarkan Gambar 2, bahwa terdapat 6 (enam) prinsip yang harus 
dipenuhi oleh media sosial pemerintah diantaranya yakni, Pertama, Kredibel yakni bahwa informasi yang diberikan dalam media sosial harus sesuai fakta dan seimbang. Kedua, Integritas yakni dalam menyampaikan informasi mengutamakan kejujuran dan etika. Ketiga, Profesional yakni pengelola media sosial harus berbasis pada keahlian, pendidikan dan keterampilan dibidangnya. Keempat, Responsif yakni selama mengoperasikan media sosial hendaknya selalu sigap dalam memberikan respon dan menerima masukan dari masyarakat. Kelima, Terintegrasi adalah keterkaitan sistem dan program dengan media komunikasi yang dimiliki baik online dan offline. Keenam, Keterwakilan yakni terkait konten dan muatan informasi yang diberikan dalam media sosial harus merepresentasikan lembaga bukan individu. Seluruh akun media sosial sudah terverifikasi dengan bukti centang biru pada setiap media sosial yang dimiliki LIPI. Menurut Tsimonis\&Dimitriadis, (2014:330) melalui media sosial, organisasi dapat menjalin hubungan dengan publik baru atau lama yang kemudian membentuk komunitas untuk melakukan kolaborasi secara interaktif untuk secara bersama- sama mengidentifikasi masalah dan memberikan solusi atas permasalahan tersebut.

Menurut Geoffrey J Simmons (2007) terdapat istilah internet branding yakni branding yang memperhatikan 4 (empat) pilar yakni memahami publik, kedua, melakukan komunikasi dua arah dengan publik, menjaga komunikasi efektif dengan publik, dan memperkuat konten di media sosial. Seperti yang dijelaskan berikut ini,

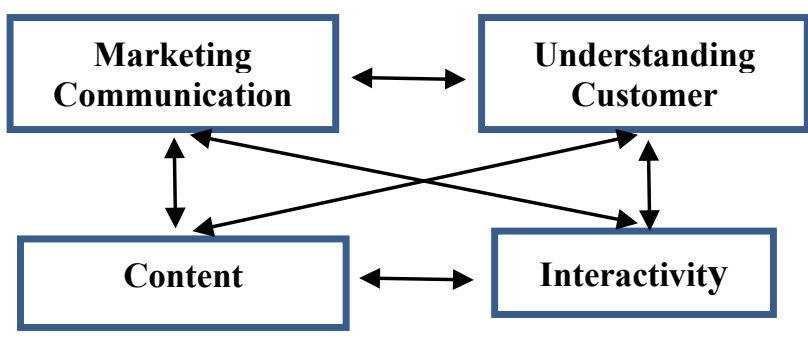

Sumber:

Simmons (2007:545)

Gambar 3. Konsep

\section{I-Branding}

Sesuai dengan konsep I-Branding, Tim Humas LIPI memahami pentingnya untuk memahami publik atau Understanding Customer. Hal ini penting agar kemudian menjadi acuan untuk mengklasifikasi publik berdasarkan ketertarikan mereka terhadap jenis informasi sains sehingga dapat lebih memuaskan publik. Selain 
itu, dalam aspek marketing communication, Tim Humas LIPI menyadari bahwa brand harus mampu dipahami oleh publik secara tepat. Untuk itu, diperlukan komunikasi dua arah dan menjalin sebuah komunikasi positif dengan selalu merespon publik (Simmons, 2007:545). Tim Humas LIPI juga menjaga interaksi interactivity atau menciptakan wadah diskusi dan menstimulasi publik memberikan riviu tentang brand. Hal ini biasanya dilakukan Tim Humas LIPI dengan menjawab setiap komentar dan pertanyaan secara atraktif sehingga terbentuk ruang diskusi. Keempat adalah content atau konten informasi dalam media sosial. Semakin unik konten maka publik akan lebih tertarik dan membaca muatan informasinya (Simmons,2010:430). Selain itu, factor terpenting adalah memberikan kemudahan pada pengguna untuk menemukan informasi terkait sains dan iptek sehingga publik diharapkan dapat terus mengakses media sosial lembaga. Tim Humas LIPI memahami bahwa empat pilar dalam internet branding harus dipenuhi oleh media sosial yang dikelolanya agar proses branding yang sedang dijalankan dapat meningkatkan image dan citra positif lembaga sekaligus menjadikan media sosial LIPI sebagai rujukan informasi iptek dan inovasi oleh masyarakat.

Setelah melakukan analisis pada digital branding yang dilakukan melalui media sosial oleh LIPI, maka dapat diketahui manfaat dari penggunaan media sosial sebagai sarana digital branding sesuai dengan teori manfaat digital branding menurut Tsimonis\&Dimitriadis yakni. Pertama, brand dapat efektif membantu mengembangkan hubungan baik dengan publik. Menurutnya, media sosial dapat menemukan target khalayak baru dan memperkuat komunikasi baik antara organisasi dengan publiknya. Hal ini dirasakan oleh Tim Humas LIPI selama mengelola media sosial, LIPI mampu berkomunikasi dan berinteraksi secara efektif dengan publiknya. Kedua, melalui media sosial, organisasi dapat menjangkau publik dan khalayak yang sebelumnya tidak tersentuh. Menurutnya, media sosial sepeti membangun sebuah jaringan dunia kecil yang menghubungkan penggunanya dalam sebuah lingkaran. Sehingga sebuah informasi dapat dengan mudah disebarkan kepada sesama pengguna selama informasi tersebut penting untuk diketahui dan bermanfaat. Ketiga, 
media sosial membantu membangun brand awareness. Media sosial dapat membantu organisasi memperkenalkan brand kepada ribuan pengguna. Hal ini dilakukan LIPI dengan melakukan promosi melalui feature berbayar yang disediakan oleh media sosial untuk mempromosikan konten informatifnya dengan tujuan menjaring followers baru. Selain itu, semakin sering brand muncul dalam jaringan media sosial, maka pengguna akan semakin akrab dengan brand tersebut. Keempat, media sosial dapat meningkatkan penjualan. Hal ini dialami LIPI terutama saat memberikan informasi terkait promosi Lomba Karya Ilmiah Remaja (LKIR), National Young Inventor Awards (NYIA), dan Indoensia Science Expo (ISE) yang setiap tahun diselenggarakan LIPI. Tim Humas LIPI membuat konten terkait event-event tersebut kemudian di share diberbagai platform media sosial sehingga selama ini kegiatan tersebut selalu ramai diikuti publik dan sukses dilakukan. Selama kegiatan Tim Humas juga selalu mengupdate jalannya kegiatan tersebut sehingga dapat menjadi trending topic di media sosial. Hal ini tentunya sangat berdampak positif pada brand awareness dan citra positif lembaga. Meskipun dengan keterbatasan yang dihadapi, media sosial LIPI memiliki followers terbanyak diantara media sosial milik LPNK Kemenristek lainnya. Selama melakukan analisis ini, strategi digital branding melalui media sosial masih terus dilakukan oleh LIPI secara konsisten agar media sosial menjadi rujukan informasi sains dan tercapai citra positif.

\section{SIMPULAN}

Strategi digital branding yang dilakukan melalui media sosial LIPI oleh Tim Humas bertujuan agar tercapainya image positif, menjadi rujukan informasi sains yang terverifikasi dan meraih brand awareness. Tim Humas LIPI telah membuat perencanaan srategi yang dilakukan diantaranya dengan melakukan pemetaan khalayak pada setiap media sosial yang dimiliki sehingga dapat melakukan penyesuaian pada bentuk kontennya. Selain itu, konten dalam media sosial berisi hasil riset dan inovasi bukan informasi yang bersifat seremonial. Dalam membuat perencanaan strategi digital Branding, Tim Humas LIPI menggunakan pendekatan Situation, Objectives, 
Strategy, Tactics, Action and Control.

Sehingga perencanaan disusun optimal.

Lebih lanjut, dalam menurunkan perencanaan menjadi sebuah startegy khususnya dengan pendekatan digital branding, Tim Humas LIPI membuat taktik strategi dengan konsep $I$ Branding yakni dengan marketing communication, understanding customer, interactivity dan content.

Adapun strategi Tim Humas LIPI yakni, memetakan konten sesuai dengan khalayak pada platform media sosial, memperhatikan penamaan media sosial, mengadakan kuis berhadiah, menampilkan konten yang bersifat sains bukan informasi seremonial, membuat kebijakan bahwa konten yang dimuat harus memiliki lisensi dan telah dipublikasi secara kode etik ilmiah, membuat klasifikasi konten berdasarkan rumpun ilmu pengetahuan, dan menarik SDM dari usia generasi millenials, menggunakan bahasa popular dan banyak menggunakan infografis. Selain itu, proses perumusan konten dilakukan melalui rapat berkala agar dapat menentukan target-target publikasi.

Meskipun memiliki 4 (empat) jenis media sosial yakni Facebook, Instagram, Twitter, dan Youtube, setiap platform tersebut memiliki jumlah followers yang berbeda. Media sosial Instagram menjadi salah satu media sosial yang memiliki jumlah followers terbanyak diantara akun Instagram milik LPNK. Hal ini membuat Tim Humas LIPI melakukan fokus digital branding pada Instagram. Proses digital branding juga dilakukan dengan metode paid promote atau promosi media sosial di layanan Instagram.

Adapun masukan yang dapat dilakukan oleh Tim Humas LIPI yakni lebih berani mengeksplorasi hasil riset yang sudah dilakukan dan memiliki sisi unik untuk kemudian diposting di media sosial. Penelitian tentang bidang Ilmu Pengetahuan Sosial dan Kemanusiaan masih jarang dibahas dibandingkan muatan konten tentang ilmu hayati, teknik dan kebumian. Hal ini penting karena masalah sosial adalah dinamika yang sering terjadi dimasyarakat. Sehingga hasil riset bidang sosial dapat membantu masyarakat dan menjadi solusi permasalahan sosial yang terjadi.

Humas LIPI memiliki hambatan yang dihadapi seperti keterbatasan SDM millenial yang tertarik pada konten kreatif media sosial, keterbatasan pendanaan, dan keterbatasan pada peralatan pendukung. Hambatan tersebut dapat diatasi dengan sharing 
pengetahuan antara pengelola media sosial, dan mengoptimalkan penggunaan alat untuk mendapatkan hasil yang maksimal. Media sosial LIPI meskipun dengan keterbatasan pada peralatan dan pendanaan namun telah mampu menjadi referensi dan rujukan informasi sains oleh publik. Hal ini dapat dibuktikan dengan jumlah followers terbanyak dibandingkan media sosial Instagram milik LPNK.

Selain itu, Tim Humas LIPI juga telah membuat perencanaan pengelolaan media sosial dapat lebih memfokuskan pada proses pembentukan branding LIPI sebagai lembaga riset yang humanis dan solutif menjawab permasalahan masyarakat sehingga dapat terbentuk citra positif lembaga. Strategi digital branding melalui media sosial cukup efektif dalam membangun brand lembaga pemerintah yang dahulu tua dan birokratis. Media sosial terbukti dapat meningkatkan komunikasi efektif antara masyarakat dan LPNK dalam menyampaikan aspirasi dan masukan terkait konten sains dan iptek. Hal ini tentunya dapat membentuk citra positif LIPI dimasyarakat.

\section{DAFTAR PUSTAKA}

Cangara,H. 2014. Pengantar Ilmu Komunikasi. Jakarta: Raja Grafindo Persada.

Chaffey, D. a. 2013. Emarketing excellence; Planning and optimizing your digital marketing. 4th edition. New York: Routledge.

Darmadi Durianto, S. d. 2004. Strategi Menaklukkan Pasar Melalui Riset Ekuitas dan Perilaku Merek. Jakarta: PT.Gramedia Pustaka Utama.

Dodwani, B., \& Agarwal, S. (Volume-6, Issue-1, 2017). Digital Branding. International Journal of Research and Development -A Management Review (IJRDMR), 3136.

Effendy, O. U. 2003. Ilmu Teori dan Filsafat Komunikasi. Bandung: PT. Citra Aditya Bakti.

Gurau, C. 2008. Integrated online marketing communication: implementation and management. Journal of Communication Management 12 (2), 169-184.

Herdiansyah, H. 2010. Metode Penelitian Kualitatif untuk Ilmu-ilmu Sosial. Jakarta: Salemba Humanika.

Hidayat, S., \& Sedarmayanti, d. 2002. Metodologi Penelitian. Bandung: Mandar Maju.

Kaplan, A. M. 2010. Users of The World, Unite! The Challenges and Opportunities of Social Media. The International Journal on Media Management, 60-68.

Kotler, P. \&.2008. Manajemen Pemasaran Jilid 2 Edisi 13. Terjemahan Bob Sabran. Jakarta: Penerbit Erlangga.

Kotler, P.2009. Manajemen Pemasaran (Marketing Management) (Edisi 13). USA: Pearson Prentice Hall. 
Kriyantono, R. 2006. Teknik Praktis Riset Komunikasi. Jakarta: Kencana.

Lengkong, S. L., sondakh, M., \& Londa, J.2017. Strategi Public Relations Dalam Pemulihan Citra Perusahaan . e-journal "Acta Diurna" Volume VI. No. 1. , 1-11.

Lotta Bäck, E. I.-J. 2018. Digital Brand Management: A Company and Consumer Perspective. Arcadia Working Paper, 1-28.

Mayfield, A. 2008. What is Social Media ? London: iCrossing.

Morrison, G. a. 2015. People powered brands: How companies can inspire consumer action . Journal of Brand Strategy, 4(3) , 201-216.

Mulyana, D. 2010. Metode Penelitian Kualitatif. Bandung: PT. Remaja Rosdakarya.

Nazir, M. 2013. Metode Penelitian. Bogor: Ghalia Indonesia.

Paul, J. P.2000. Consumer Behavior: Perilaku Konsumendan Strategi Pemasaran.Terjemahan. Jakarta: Erlangga.

Philip, K., \& Armstrong, G. 2010. Prinsip-Prinsip Pemasaran Jilid 1 dan 2 edisi ke dua belas. Jakarta: Erlangga.

Phillip, K., \& Keller. 2016. Marketing Management 16th Edition. New Jersey: Pearson.

Pratama, D.2012. Strategi komunikasi dalam penyebaran informasi di PT. Chevron Indonesia. Jurnal Kajian Komunikasi Unpad, 1-22.

Putri\&Mardalis, A.2017. Analisis Pengaruh Media Sosial Instagram Terhadap Pembentukan Brand Attachment(Studi : Universitas Muhammadiyah Surakarta). Solo: Universitas Muhamadiyah Surakarta.

Rustandi, F. O. (Volume 3, No. 1, 2018). Implementasi Digital Marketing dalam Membangun Brand Awareness . PRofesi Humas, 1-20.

Ryan, D. a.2009. Understanding Digital Marketing - Marketing strategies for engaging the digital generation. London and Philadelphia: Kogan Page.

Setiawan, D.2017. Dampak Perkembangan Teknologi dan Komunikasi Terhadap Budaya. Simbolika, 62-73.

Simmons, G. 2007. "i-Branding": developing the internet as a branding tool. Marketing Intelligence\&Planning 25 (6), 544-562.

Simmons, G. T. 2010. Managing i-branding to create brand equity. European Journal of Marketing, 44(9/10) , 1260-1285.

Soraya, I. (Volume VIII Nomor 2, September 2017 ). Personal Branding Laudya Cynthia Bella Melalui Instagram (Studi Deskriptif Kualitatif Pada Akun Instagram@Bandungmakuta).Jurnal Komunikasi,30-38.

Tsimonis, G. a.2014. Brand strategies in social media . Marketing Intelligence \& Planning, 328-344.

Tumakaka, N. P., Dida, S., \& Prastowo, F. A. 2019. Personal Branding Rachel Goddard Sebagai Beauty Travel Dan Parody Vlogger. Acta Diurna Vol.15 No.2, 76-97

Zarrella, D. 2009. Social Media Marketing Book. London: O’REILLY.

Website

Kementerian Pendayagunaan Aparatur Negara, (2012). Prinsip Media Sosial Humas Pemerintah. www.kemenpan.go.id diakses pada 13 Mei 2020 